\title{
Perbedaan Cara Menjawab Pertanyaan Antara Mahasiswa Laki-Laki Dan Perempuan Dengan Menggunakan Konsep R3Mr
}

\author{
Suryawahyuni Latief \\ Sekolah Tinggi Ilmu Sosial Ilmu Politik Nurdin Hamzah, Jambi, \\ Indonesia
}

Abstract: The main purpose of this study is to know about the differences between gender and style of answer the question of undergraduate students in $V$ semester of Government Science field, Syariah Faculty, UIN Sulthan Thaha Syaifuddin, Jambi, 2018/2019 academic year. This study employed statistic descriptive analyze by chi-square and determined four variable, named R3Mr. The study found that there is a difference between gender and style of answer question, which is male students dominated in R1 and Mr variable, the percentage of $\mathrm{Rl}$ and $\mathrm{Mr}$ variable are $70.7 \%$ and $62.5 \%$, while the female students are in $R 2$ and $R 3$ variable, that is $62.5 \%$ and $53.3 \%$

Keywords: Gender and communication, $\mathrm{R} 3 \mathrm{Mr}$

\section{Pendahuluan}

Penelitian terkait laki-laki dan wanita, yang diistilahkan dengan gender telah banyak dilakukan oleh penelitian terdahulu, seperti penelitian terkait respon atas pujian (Mustofa, 2015, p.56), komunikasi (Nevala, 2015, p.24), persepsi terhadap mentoring (2018) dan gaya belajar (Shuib \& Norbaya, 2015, p.76). Sedangkan menurut Roman dan Gioricelaya (2012) melakukan penelitian mengenai perbedaan nilai tes antara pelajar laki-laki dan perempuan, dan Lawton dan Hatcher (2005) tentang perbedaan kemampuan spasial. Perbedaan tersebut tidak mempengaruhi hak dan kedudukan perempuan dalam beberapa bidang kehidupan, seperti pendidikan. Perempuan dan laki-laki memiliki kesempatan yang sama untuk mendapatkan pendidikan mulai dari 
pendidikan dasar hingga pendidikan tinggi sesuai dengan tujuan masa depan individu tersebut.

Perempuan dan laki-laki memiliki perbedaan baik secara biologis, penampilan, dan emosional, maupun perannya. Menurut Helgeson (2012) laki-laki memiliki karakter maskulin yaitu sangat agresif, mandiri tidak emosional, dominasi, sangat percaya diri, menyukai sesaga sesuatu yang besifat sains, sangat mudah membuat keputusan dan lainsebagainya, sementara perempuan berkarakter feminim, yaitu kebalikan dari karakter maskulin.

Mahasiswa laki-laki dan perempuan memiliki perbedaan dalam proses pembelajaran seperti sikap duduk, bertanya, maupun berinteraksi. Perbedaan tersebut sangat menarik untuk dilakukan kajian dalam upaya memahami perbedaan antara mahasiswa laki-laki dan perempuan dan menemukan pola yang tepat bagi pendidik dalam kegiatan pembelajaran. Penelitian terkait gender memiliki tiga alasan menurut Programme for International student assessment dalam Halparn (2012) adalah untuk memamhami sumber dari perbedaan atau ketidaksamaan tersebut, untuk meningkatkan kinerja rata-rata dan untuk meningkatkan pemahman bagaimana cara belajar peserta didik. Oleh karena itu,penelitian terkait gender merupakan hal yang layak untuk dikaji.

Berdasarkan uraian di atas, penelitian ini bertujuan untuk mengetahui apakah terdapat hubungan antara jenis kelamin dan gaya menjawab pertanyaan. 


\section{Landasan Teori}

\section{Pandangan Sikap terhadap laki-laki dan Perempuan}

Menurut Helgeson (2012, p.68), ada tiga komponen sikap yang berkaitan dengan permasalahan gender yaitu affect (feelings), cognition (beliefs), dan behavior. Affect (feelings) adalah komponen yang menunjukkan pada suatu keinginan yang mempengaruhi sebuah perilaku. Perasaaan masyarakat terhadap gender digambarkan dengan istilah sexism atau jenis kelamin, peran atau stereotype dan perilaku yang membedakan antara laki-laki dan perempuan. Kategori komponen sikap yang kedua adalah cognition (beliefs) adalah adanya perbedaan pandangan terhadap pemikiran atau pengetahuan antara laki-laki dna perempuan. Sedangkan komponen sikap yang ketiga adalah behavior (perilaku).

Pandangan tentang gender berdasarkan hasil kajian yang telah dilakukan oleh para peneliti terdahulu, terdapat tiga ideologi gender yaitu tradisional, egalitarian, dan transisisional (Helgeson, 2012, p.68). Ideologi tradisional menyatakan bahwa laki-laki tempatnya bekerja, dan perempuan di rumah, sedangkan dalam paham egalitarian, antara laik-laki dan perempuan memiliki kesamaan baik di rumah, di tempat kerja, maupun di tempat lainnya. Paham gender lainnya yang disebut transisional adalah beranggapan bahwa perempuan yang bekerja tetap saja harus mengutamakan keluarganya atau bertanggungjawab terhadap pekerjaan di rumah sebagai seorang ibu ataupun istri, sementara lakilaki harus totalitas dalam bekerja.

\section{Gender dan Perbedaannya}

Halparn (2012) mengemukakan bahwa perempuan belajar membaca pada usia yang sangat muda daripada laki-laki, atau laki-laki 
sangat cepat dalam melaksanakan tugas yang diminta. Brovermen dalam Helgeson (2012, p.81), menyatakan bahwa perbedaan antara laki-laki dan mahasiswa terletak pada beberapa fitur yaitu laki-laki lebih fokus pada kompetensi, rasional, dan tegas; sedangkan perempuan ramah dan ekspresif. Duff dan Hampson dalam Lewin (2003) menyatakan bahwa antara laki-laki dan perempuan memiliki perbedaan yaitu dalam spatial abilities yaitu dalam kegiatan menyampaikan informasi, transformasi informasi, mengulang informasi dan informasi yang bersifat linguistik; keterampilan motorik (motoric skills) yaitu laki-laki lebih memiliki keterampilan motorik dibanding perempuan; dan attention yaitu sebuah kemampaun memilih stimulus untuk proses berikutnya melalaui informasi yang tersedia.

\section{Komunikasi dan Bahasa}

Individu dalam kehidupan sehari-harinya menggunakan bahasa untuk saling berbagi informasi yang dilakukan melalui komunikasi, baik berupa kata, simbol maupun gesture, karena komunikasi dan bahasa merupakan kegiatan penting dalam setiap bentuk dan tingkatan pendidikan serta syarat utama dalam kegiatan pendidikan (Jordan, Carlile, \& Stack, 2008, p.184). Menurut Helgeson (2012, p.231) perbedaan bahasa antara laki-laki dan perempuan terlihat dari bberapa fitur, seperti pada tabel. 1 .

\section{Tabel 1}

\section{Perbedaan Bahasa Laki-Laki Dan Perempuan}

\begin{tabular}{lll}
\hline Fitur & Contoh Kata & Gender \\
\hline Self-references (penunjukkan diri) & $\mathrm{Aku}$ & Laki- laki \\
Directive/Imperative & Tutup pintu! & Laki-laki \\
(mengarahkan/ memerintah) & &
\end{tabular}


Quantity term ( term jumlah)

Intensive adverb (kata keterangan intensif)

Hedges (penyangkalan kat $a$ )

Use emotion (menggunakan emosi)

Ask question (bertanya)

Exclamation (eklamasi)

Sentence length (panjang kalimat)
Lima mil

"Jadi"; "yang Perempuan

benar"

"mungkin",

"dapat"

"mengapa"

"Wow"

"Kalimat

panjang"
Perempuan

Perempuan

Perempuan

Perempuan

Perempuan

Minimal response (respon minimal) “oke". "Hmmm" Perempuan

\section{Sumber: Helgeson (2012, p.231)}

Selanjutnya Mulac, Bradac, \& Gibson (2001) membagi tiga dimensi bahasa antara laki-laki dan perempuan, yaitu: 1) laki-laki dalam berkomunikasi lebih spontan dan langsung, sedangkan perempuan dalam berkomunikasi perempuan mengulangi pertanyaan dan menggunakan kata yang bersifat kualifikasi seperti andaikan, kecuali dan lain sebagiainya, serta menggunakan kata pengelakkan (hedges) yaitu kata-kata yang menyembunyikan komitmen seperti "mungkin", "dapat", dan“sekitar"; 2) perempuan dalam berkomunikasi menggunakan kalimat atau bahasa yang panjang dan lebih elaborasi dibanding laki-laki; dan 3) laki-laki dalam komunikasi lebih tegas, terarah, dan ringkas dibandingkan perempuan.

Berdasarkan uraian tentang gender di atas, maka dapat disimpulkan bahwa antara laki-laki dan perempuan memiliki perbedaan baik dari segi biologis, bahasa, sikap maupun pemikiran.

\section{Metode Penelitian}




\section{Tujuan Penelitian}

Penelitian ini menggunakan pendekatan kuantitatif untuk melihat perbedaan dan persamaan gaya menjawab pertanyaan antara mahasiswa laki-laki dan perempuan. Penelitian ini bertujuan untuk melihat apakah terdapat hubungan antara jenis kelamin dengan gaya menjawab pertanyaan yang diberikan. Variabel dalam penelitian ini penulis sebut R3Mr, yaitu:

1) Respond directly yaitu mahasiswa ketika diberikan pertanyaan menjawab secara langsung.

2) Respon by hedges, yaitu mahasiswa menjawab pertanyaan seraya menggunakan kalimat pengelakkan seperti kata "mungkin" dan lain sebagainya.

3) Respon by using long sentence, yaitu mahasiswa menjawab pertanyaaan dengan menggunakan kalimat yang panjang.

4) Minimal Respond, yaitu mahasiswa menjawab secara ringkas.

\section{Subjek Penelitian}

Subjek penelitian adalah mahasiswa Fakultas Syariah, Program Studi Ilmu Pemerintahan UIN Sulthan Thaha Syafuddin Jambi semester V A, V G, V H dalam mata kuliah komunikasi pemerintah pada tahun 2018 dengan jumlah mahasiswa sebanyak 112 orang dengan rincian pada tabel berikut:

\section{Tabel 1}

Jumlah Mahasiswa Fakultas Syariah Program Studi Ilmu Pemerintahan

\begin{tabular}{cccc}
\hline Kelas & \multicolumn{2}{c}{ Mahasiswa } & Jumlah \\
& Laki-Laki & Perempuan & \\
\hline VA & 22 & 18 & 40
\end{tabular}


VG

$\mathrm{VH}$

19

15

34

Total

60

52

112

Penelitian dilakukan pada bulan Oktober sampai Desember 2018.

\section{Teknik Analisis Data}

Teknik analisis data adalah melalui uji statistik, setelah data dikumpulkan oleh peneliti dengan menggunakan analisis chi square karena terkait pengujian terhadap perbedaab jenis kelamin dan gaya menjawab pertanyaan yang diberikan.

\section{Hasil Dan Pembahasan}

\section{Analisis Deskriptif Statistik}

Objek dalam penelitian ini adalah mahasiswa semester V kelas A, G, dan H Fakultas Syariah, Program Studi Ilmu Pemerintahan UIN Sulthan Thaha Syaifuddin Jambi. Jumlah populasi yang digunakan dalam penelitian ini adalah 112 mahasiwa. Hasil analisis deskriptif terkait perbedaan jenis kelamin dan gaya menjawab pertanyaan dengan menggunakan SPSS 18 adalah sebagai berikut:

Tabel 3.

Data Validitas Deskriptif Analitis Gaya Menjawab dan Jenis Kelamin

\begin{tabular}{|l|r|r|r|r|r|r|}
\hline \multirow{1}{*}{} & \multicolumn{6}{|c|}{ Cases } \\
\cline { 2 - 7 } & \multicolumn{2}{|c|}{ Valid } & \multicolumn{2}{c|}{ Missing } & \multicolumn{2}{c|}{ Total } \\
\cline { 2 - 7 } & $\mathrm{N}$ & $\mathrm{t}$ & $\mathrm{N}$ & $\mathrm{t}$ & $\mathrm{N}$ & $\mathrm{t}$ \\
\hline Gaya Menjawab * \\
Jenis Kelamin
\end{tabular}


Hasil output deskriptif statistik validitas data pada tabel 3 terlihat bahwa nilai valid sebesar $100 \%$, hal ini menunjukkan bahwa data jenis kelamin dan gaya menjawab mahasiswa berjumlah 112 dan tidak ada data yang hilang.

Selanjutnya, tabel 4 menggambarkan distribusi jenis kelamin dan gaya menjawab mahasiswa program studi ilmu pemerintahan pada mata kuliah komunikasi pemerintahan.

Tabel 4.

\section{Distribusi Jenis Kelamin dan Gaya Menjawab}

\begin{tabular}{|c|c|c|c|c|c|}
\hline & & & \multicolumn{2}{|c|}{ Jenis Kelamin } & \multirow[b]{2}{*}{ Total } \\
\hline & & & $\begin{array}{l}\text { laki- } \\
\text { laki }\end{array}$ & $\begin{array}{c}\text { Peremp } \\
\text { uan }\end{array}$ & \\
\hline \multirow{12}{*}{$\begin{array}{l}\text { Gaya } \\
\text { Menjawab }\end{array}$} & Respond directly & Count & 29 & 12 & 41 \\
\hline & & $\%$ within Gaya & 70.7 & $29.3 \%$ & 100.0 \\
\hline & & Menjawab & $\%$ & & $\%$ \\
\hline & Respond by & Count & 12 & 20 & 32 \\
\hline & hedges & $\%$ within Gaya & 37.5 & $62.5 \%$ & 100.0 \\
\hline & & Menjawab & $\%$ & & $\%$ \\
\hline & Respond by using & Count & 7 & 8 & 15 \\
\hline & long sentences & $\%$ within Gaya & 46.7 & $53.3 \%$ & 100.0 \\
\hline & & Menjawab & $\%$ & & $\%$ \\
\hline & minimal respond & Count & 15 & 9 & 24 \\
\hline & & $\%$ within Gaya & 62.5 & $37.5 \%$ & 100.0 \\
\hline & & Menjawab & $\%$ & & $\%$ \\
\hline Total & & Count & 63 & 49 & 112 \\
\hline
\end{tabular}


Tabel 4.

Distribusi Jenis Kelamin dan Gaya Menjawab

\begin{tabular}{|c|c|c|c|c|c|}
\hline & & & Jenis & Kelamin & \\
\hline & & & $\begin{array}{l}\text { laki- } \\
\text { laki }\end{array}$ & $\begin{array}{c}\text { Peremp } \\
\text { uan }\end{array}$ & Total \\
\hline Gaya & Respond directly & Count & 29 & 12 & 41 \\
\hline Menjawab & & $\%$ within Gaya & 70.7 & $29.3 \%$ & 100.0 \\
\hline & & Menjawab & $\%$ & & $\%$ \\
\hline & Respond by & Count & 12 & 20 & 32 \\
\hline & hedges & $\%$ within Gaya & 37.5 & $62.5 \%$ & 100.0 \\
\hline & & Menjawab & $\%$ & & $\%$ \\
\hline & Respond by using & Count & 7 & 8 & 15 \\
\hline & long sentences & $\%$ within Gaya & 46.7 & $53.3 \%$ & 100.0 \\
\hline & & Menjawab & $\%$ & & $\%$ \\
\hline & minimal respond & Count & 15 & 9 & 24 \\
\hline & & $\%$ within Gaya & 62.5 & $37.5 \%$ & 100.0 \\
\hline & & Menjawab & $\%$ & & $\%$ \\
\hline Total & & Count & 63 & 49 & 112 \\
\hline & & $\%$ within Gaya & 56.3 & $43.8 \%$ & 100.0 \\
\hline & & Menjawab & $\%$ & & $\%$ \\
\hline
\end{tabular}

Berdasarkan hasil output analisis dengan menggunakan statistik analisis apakah ada perbedaan antara jenis kelamin dan gaya menjawab antara mahasiswa laki-laki dan perempuan ditunjukan oleh tabel 4 , yang dapat diuraikan sebagai berikut: 
1. Respond Directly (R1) yaitu memiliki pengertian bahwa mahasiswa dalam menjawab pertanyaan yang diberikan menjawab secara langsung dengan bahasa yang lugas tanpa terbata-bata. Tabel 4 menunjukkan bahwa mahasiswa laki-laki memiliki persentase sebesar $70,7 \%$ pada variabel menjawab pertanyaan secara langsung (R1) dan mahasiswa perempuan sebesar $29.3 \%$

2. Respond by hedges (R2) merupakan gaya menjawab mahasiswa dengan menggunakan kata-kata yang bersifat pengelakkan atau penyangkalan seperti "mungkin, " dapat", dan "sekitar". Pada variabel R2 persentase gaya menjawab mahasiswa perempuan sebesar $62.5 \%$ dan mahasiswa laki-laki sebesar 37.5\%.

3. Respond by using long sentence (R3) yaitu gaya menjawab pertanyaan dengan menggunakan kalimat panjang atau mendetail dalam menjelaskan. Gaya menjawab mahasiswa laki-laki sebesar $46.7 \%$ dan mahasiswa perempuan sebesar $53.3 \%$

4. Minimal respond (Mr), yaitu gaya menjawab pertanyaan yang singkat yaitu "oke", "baik", dan "setuju". Pada variabel Mr, gaya menjawab pertanyaan mahasiswa perempuan adalah sebesar $37.5 \%$ dan mahasiswa laki-laki sebesar $62.5 \%$

Tabel 5 merupakan tabel untuk mengetahui apakah terdapat hubungan antara jenis kelamin dengan gaya menjawab. Berdasarkan tabel 5, terlihat bahwa signifikan sebesar 0.045 yaitu lebih kecil dari 0.05, maka dapat disimpulkan bahwa terdapat hubungan antara jenis kelamin dan cara menjawab pertanyaan. 
Tabel 5.

Chi-Square Tests

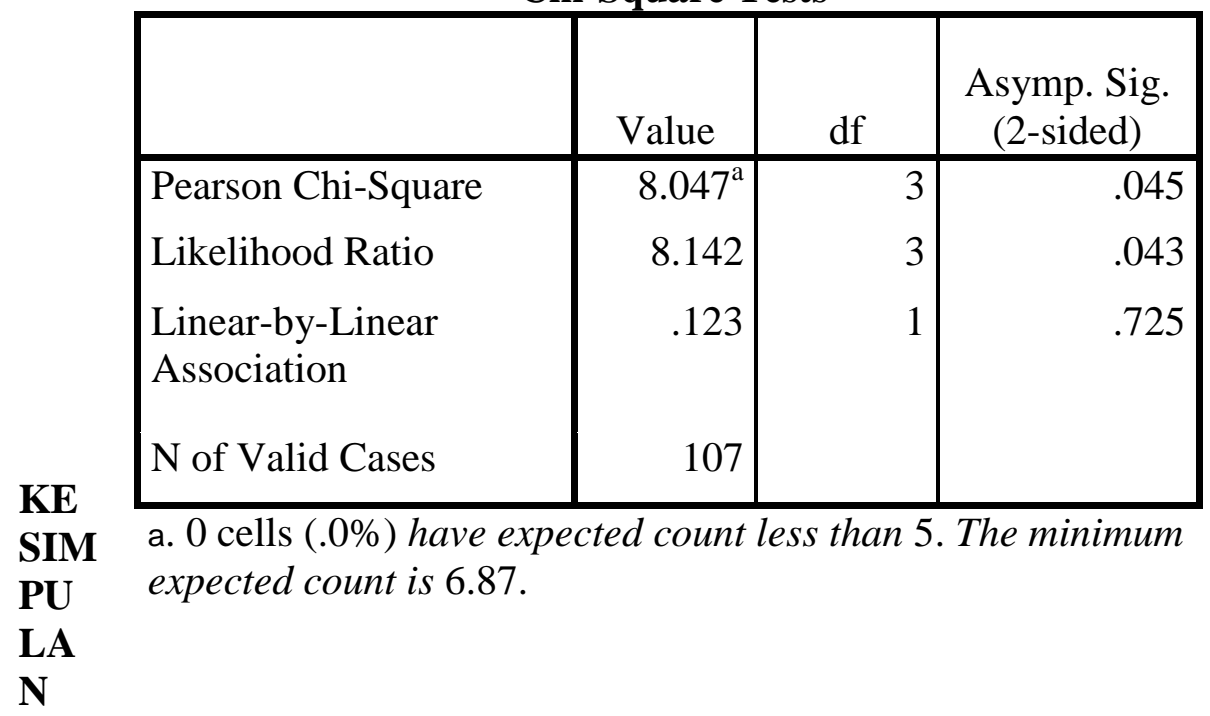

Berpijak pada pada analisis hasil dan pembahasan, maka peneliti dapat menyimpulkan bahwa:

1. Terdapat hubungan signifikan antara jenis kelamin dan gaya menjawab, yaitu:

a. Dari semua variabel gaya menjawab, terlihat bahwa variabel respon directly (R1) merupakan gaya menjawab yang didominasi oleh mahasiswa laki-laki sebesar 70. 7\% dan variabel minimal respond (Mr) sebesar $62.5 \%$.

b. Sementara, mahasiswa perempuan dalam menjawab pertanyaan yang diberikan mendominasi pada variabel respond by hedges (R2) sebesar $62.5 \%$ dan repond by using long sentence (R3) yaitu $53.3 \%$

2. Dari analisis hasil dan pembahasan terlihat bahwa mahasiswa perempuan menominasi gaya menjawab dengan menggunakan kalimat penyangkalan atau pengelakan dan kalimat yang panjang saat menjelaskan jawaban atas pertanyaan yang diberikan, sementara mahasiswa laki-laki menjawab pertanyaan secara langsung, tegas, dan lugas.

\section{Daftar Rujukan}

Greene O. J., \& Burleson R. B. 2008. Handbook of communication and social interaction skills. New Jersey: Lawrence Erlbaum Associates. 
Suryawahyuni Latief

Helgeson, S.V. 2012. The psychology of gender, fourth edition. Boston: Pearson.

Hill, A. M. 2018. Publikasi Tesis, the perceived mentoring experiences of male and female doctoral students in sociology. Retrieved from https://scholarship.shu.edu/dissertations pada tanggal 12 April 2019.

Halpern, D.F. 2012. Sex Differences in Cognitive Abilities. New York: Taylor and Francis.

Jordan, A., Carlile, O., \& Stack, A. 2008. Approach to Learning: A Guide for Teacher. England: McGraw-Hill Open University Press.

Lewin, C. 2003. Sex differences in Memory and Other Cognitive Abilities. Stockholm: Stockholm University.

Mostofa, M. 2015. Publikasi Tesis , a study compliment responses among male and female Egyptian undergraduate students. Retrieved from https://dar.aucegypt.edu/bitstrean/handle/10526/4390/thesisimariam mustofa.pdf? pada tanggal 12 April 2019.

Mulac, A., Bradac, J.J., \& Gibbons, P. 2001. Empirical support for the gender-as-culture hypothesis: an intercultural analysis of male/female language difference. Human Communication Research, 27, 121-152.

Nevala, N. 2015. Publikasi Tesis, female style Vs. male style or something in between? A case study on gendered communication on humans of New York facebook page. Retrieved from https://jyx.jyu.fi/bitstream/handle/123456789/48023/5/urn_nb n_fi-jyu-2015 pada tanggal 12 April 2019.

Roman, A.G., \& Goiricelaya, R.D. 2012. Gender gaps in PISA test scores: the impact of social norms and the mother's transmission of role attitudes.diakses dari ftp.iza.orf/dp6338.pdf pada tanggal 30 April 2019.

Shuib, M., \& Norbaya, S. 2015. Learning style preferences among male and female ESL students in Universiti-Saina Malaysia. The journal of educators online-JEO, Vol.13, No.2, 103-141. ISSN 1547-500X. 